\title{
C-raf Antisense Oligonucleotide ISIS 5132
}

National Cancer Institute

\section{Source}

National Cancer Institute. c-raf Antisense Oligonucleotide ISIS 5132. NCI Thesaurus.

Code C2721.

A synthetic, 20-base antisense oligodeoxynucleotide that hybridizes to c-raf kinase messenger RNA. ISIS 5132 has been shown to specifically suppress Raf-1 expression both in vitro and in vivo. Raf-1 serine/threonine kinase functions as a critical effector of Ras-mediated signal transduction; constitutive activation of this pathway directly contributes to malignant transformation. ( $\mathrm{NCl04)}$ 